\title{
Analisis Peranan Sektor Pertanian di Provinsi Nusa Tenggara Timur
}

Fadhlan Zuhdia

aBalai Pengkajian Teknologi Pertanian Riau, Indonesia. Email: fadhlanzuhdi21@gmail.com

\section{Article Info}

Article history:

Received 8 Januari 2021

Received in revised form 15 Januari 2021

Accepted 20 Januari 2021

DOI:

https://doi.org/10.32938/ag.v6i1.1241

Keywords:

Agriclutural Sector

Economic Growth

Nusa Tenggara Timur Province

\section{Abstrak}

East Nusa Tenggara Province (NTT) is a province that has a lot of potential natural resource due to its diverse demographics from volcanoes to savanna and steppe. This potential makes NTT Province feasible to be developed, especially in the agricultural sector. Potential analysis of the agricultural sector was carried out to measure the role of the agricultural sector for economic growth in NTT Province using the Klassen Typology Method, Location Quotient (LQ) and Shift Share analysis. The results with Klassen Typology Method show that the agricultural sector is in quadrant II, which is an advanced but depressed sector. This reflects that the agricultural sector is the dominant sector for economic growth in NTT Province during the analysis period. However, over time, other sectors had faster growth rates than the agricultural sector. In addition, the results of the $L Q$ analysis state that the agricultural sector is the basis of the sector in NTT Province, while the Shift Share analysis states that the growth of the agricultural sector in NTT Province has a faster growth than the national agricultural sector.

\section{Pendahuluan}

Provinsi Nusa Tenggara Timur (NTT) merupakan provinsi yang terdiri dari banyak pulau dengan total pulau mencapai 566 pulau, di mana luas daratan mencapai $47349 \mathrm{~km}^{2}$ dan lautan seluas $\pm 200000 \mathrm{~km}^{2}$ (Bank Indonesia, 2020). Secara proporsi, Provinsi NTT memiliki kontribusi sebesar 2.49 persen dari luas Indonesia. Meskipun memiliki kontribusi luas wilayah yang tidak besar, Provinsi NTT memiliki potensi sumberdaya alam yang tinggi. Hal tersebut dikarenakan demografi wilayah Provinsi NTT yang sebagian besar terdiri dari wilayah pegunungan dan perbukitan kapur. Selain itu, di beberapa pulau yang ada di Provinsi NTT juga memiliki padang rumput dan stepa yang luas sehingga semakin memperkaya keragaman topologi (Bank Indonesia, 2020).

Potensi besar yang dimiliki oleh Provinsi NTT dari segi topologi, telah berhasil dimanfaatkan oleh masyarakat untuk melakukan pengusahaan di sektor pertanian dan peternakan. Hal tersebut tercermin dari jumlah rumah tangga usaha pertanian yang menjadikan pertanian sebagai sumber usaha utama pada tahun 2018 hingga mencapai 818853 jiwa untuk bidang pertanian dan 41960 jiwa untuk bidang peternakan atau menyumbang sebesar 16.28 persen angkatan kerja dari jumlah penduduk. Selain itu, berdasarkan laporan (Kementerian Pertanian, 2020), padi merupakan tanaman pangan yang memiliki jumlah produksi terbesar di Provinsi NTT dengan total produksi mencapai 1090821 ton pada tahun 2017 atau berkontribusi sebesar 1.34 persen dari total produksi padi nasional. Komoditas yang memiliki nilai produksi terbesar lainnya adalah jagung dengan total produksi mencapai 809830 ton atau berkontribusi sebesar 2.79 dari total produksi jagung nasional pada tahun 2017. Dari sisi peternakan, Provinsi NTT memiliki jumlah populasi sapi potong sebanyak 1027286 ekor sapi atau berkontribusi terhadap 6.25 persen dari total populasi sapi potong nasional.

Berdasarkan data tersebut, terlihat bahwa sektor pertanian di Provinsi NTT memiliki kontribusi penting bagi masyarakat. Namun, pengembangan sektor pertanian perlahan terlupakan karena sering dianggap sebagai unsur penunjang dalam perekonomian (Sari \& Bangun, 2019). Oleh sebab itu, pengembangan sektor pertanian yang lebih masif perlu dilakukan karena dapat menjadi salah satu alternatif untuk mengurangi kesenjangan pembangunan wilayah (Hidayat \& Supriharjo, 2014). Pada tahun 2019, sektor pertanian menyumbang 27.99 persen dari total PDRB atas dasar harga konstan Provinsi NTT. Hal tersebut mengindikasikan bahwa sektor pertanian menjadi sektor yang perlu diperhatikan dan dikembangkan lebih jauh mengingat besarnya kontribusi sektor pertanian terhadap perekonomian Provinsi NTT. Penelitian ini bertujuan untuk memberikan pembahasan lebih lanjut terkait dengan kontribusi sektor pertanian bagi perekonomian Provinsi NTT sehingga dapat dijadikan landasan bagi para regulator untuk membuat kebijakan yang tepat guna demi terciptanya perekonomian yang mandiri dan maju di Provinsi NTT.

\section{Metode}

Penelitian ini menggunakan data sekunder dalam bentuk time series yang berupa Produk Regional Domestik Bruto (PDRB) dan Produk Domestik Bruto (PDB) dalam kurun waktu empat tahun (2015-2019) dengan menjadikan Provinsi NTT sebagai wilayah analisis dan Indonesia 
sebagai wilayah acuan. Pola dan struktur pertanian di Provinsi NTT akan digambarkan dengan Klassen Typology Method. Metode ini mengklasifikasikan sektor usaha menjadi empat bagian (kuadran) di mana kuadran I merepresentasikan sektor yang maju dan bertumbuh dengan pesat, kuadran II merupakan sektor yang maju namun tertekan, kuadran III merupakan sektor yang potensial dan masih dapat berkembang serta kuadran IV merupakan sektor yang secara relatif tertinggal (Ai \& Wardoyo, 2015). Pada dasarnya, tipologi wilayah dapat dibedakan menjadi dua macam pertumbuhan yaitu pertumbuhan ekonomi regional yang diklasifikasikan dengan sumbu vertikal dan pendapatan per kapita yang diklasifikasikan dengan sumbu horizontal (Supriyadi et al., 2016). Selanjutnya, Klassen Typology Method dapat diklasifikan sebagaimana disajikan pada Tabel 1.

Tabel 1. Klasifikasi Klassen Typology Method

\begin{tabular}{|c|c|}
\hline $\begin{array}{c}\text { Kuadran I } \\
\text { sektor yang maju dan tumbuh dengan pesat } \\
\mathrm{r}_{\mathrm{i}}>=\mathrm{r} \text { dan } \mathrm{y}_{\mathrm{i}}>=\mathrm{y}\end{array}$ & $\begin{array}{c}\text { Kuadran II } \\
\text { Kuadran III } \\
\begin{array}{c}\text { sektor maju tapi tertekan } \\
\mathrm{r}_{\mathrm{i}}<\mathrm{r} \text { dan } \mathrm{y}_{\mathrm{i}}>=\mathrm{y}\end{array} \\
\begin{array}{c}\text { Kuadran IV } \\
\text { sektor potensial atau masih dapat berkembang } \\
\mathrm{r}_{\mathrm{i}}>=\mathrm{r} \text { dan } \mathrm{y}_{\mathrm{i}}<\mathrm{y}\end{array}\end{array}$ \\
$\begin{array}{c}\text { sektor relatif tertinggal } \\
\mathrm{r}_{\mathrm{i}}<\mathrm{r} \text { dan } \mathrm{y}_{\mathrm{i}}<\mathrm{y}\end{array}$ \\
\hline
\end{tabular}

Sumber: (Ai \& Wardoyo, 2015)

Di mana ri merupakan pertumbuhan PDRB pada daerah i; $r$ adalah pertumbuhan PDRB pada daerah acuan; yi adalah kontribusi pertumbuhan sektor $\mathrm{x}$ di daerah $\mathrm{i}$ dan $\mathrm{y}$ adalah kontribusi pertumbuhan sektor $\mathrm{x}$ di daerah acuan.

Analisis Location Quotient (LQ) merupakan alat analisis yang digunakan untuk mengidentifikasi seberapa kuat sebuah sektor atau industri yang berada di suatu wilayah dan untuk menganalisis sektor apa saja yang menjadi unggulan pada wilayah tersebut (Morrissey, 2016). Location Quotient juga sering digunakan untuk mengidentifikasi kluster industri yang menjadi fokus pemerintah (Crawley et al., 2013). Secara matematis, Location Quotient dapat diukur menggunakan persamaan matematis sebagai berikut (Fracasso \& Marzetti, 2018; Liu et al., 2019):

$$
L Q i=((Q i j / Q i)) /((Q j / Q))
$$

Di mana Qij adalah kontribusi sektor i terhadap PDRB di wilayah analisis; Qi adalah nilai total PDRB di wilayah analisis; Qj adalah nilai kontribusi sektor i terhadap PDB di wilayah acuan dan $\mathrm{Q}$ adalah nilai total PDB wilayah acuan.

Selanjutnya, hasil dari perhitungan Location Quotient akan dikategorikan dalam tiga kategori yaitu (Jumiyanti, 2018):

1) LQ > 1 mengartikan bahwa sektor i telah menjadi sebuah basis atau sumber pertumbuhan di wilayah analisis. Hasil dari sektor i telah mampu memenuhi kebutuhan untuk wilayahnya sendiri dan surplusnya dapat dijual ke wilayah lain.

2) $\mathrm{LQ}=1$ mengartikan bahwa sektor $\mathrm{i}$ telah menjadi sebuah basis di wilayah analisis. Hasil dari sektor i telah mampu memenuhi kebutuhan untuk wilayahnya sendiri namun tidak terdapat surplus sehingga tidak dapat dijual ke wilayah lain.

3) LQ $<1$ mengartikan bahwa sektor i termasuk pada sektor non basis. Hasil dari sektor i tidak cukup untuk memenuhi kebutuhan di wilayahnya sendiri sehingga diperlukan pasokan dari wilayah luar.

Analisis Shift Share merupakan metode yang sering digunakan untuk mengukur kinerja perekonomian suatu wilayah dan membandingkannya dengan wilayah lain yang lebih luas sehingga analisis Shift Share mampu memberi gambaran terkait kekuatan dan kelemahan suatu sektor pada wilayah analisis dengan sektor yang sama pada wilayah acuan (Cieślak et al., 2019). Analisis Shift Share merupakan perubahan (D) suatu variabel pada wilayah dan waktu tertentu yang terbagi atas beberapa pengaruh yaitu pengaruh pertumbuhan nasional $(\mathrm{N})$, pertumbuhan proporsional (M) dan keunggulan kompetitif (C). Perhitungan Shift Share dapat dilakukan dengan menggunakan formula sebagai berikut (Abidin, 2015):

$$
D_{i j}=N_{i j}+M_{i j}+C i j
$$

Jika formula Shift Share diterapkan pada PDRB, maka:

$D_{i j}=Y^{*} i j-Y i j$ 
$N_{i j}=Y i j-r_{n}$

$M_{i j}=Y i j-\left(r_{i n}-r_{n}\right)$

$C_{i j}=Y i j-\left(r_{i j}-r_{i n}\right)$

Di mana $r_{i j}$, $r_{i n}$ dan $r_{n}$ adalah laju pertumbuhan wilayah analisis dan acuan yang masing-masing diturunkan sebagai berikut:

$$
\begin{aligned}
r_{i j} & =\left(Y^{*}{ }_{i j}-Y_{i j}\right) / Y_{i j} \\
r_{i n} & =\left(Y^{*}{ }_{i n}-Y_{i n}\right) / Y_{i n} \\
r_{i n} & =\left(Y^{*}{ }_{n}-Y_{n}\right) / Y_{n}
\end{aligned}
$$

Di mana $Y_{i j}$ adalah PDRB sektor I di wilayah analisis; $Y_{\text {in }}$ adalah PDRB di wilayah acuan dan $Y_{n}$ adalah PDRB wilayah acuan yang diukur pada tahun dasar.

Hasil perhitungan analisis Shift Share memberikan informasi perekonomian ke dalam tiga kelompok yaitu (Sari \& Bangun, 2019):

1) Jika nilai Nij positif mengindikasikan bahwa pertumbuhan sektor i di wilayah analisis lebih cepat jika dibandingkan dengan pertumbuhan sektor i di wilayah acuan. Sedangkan apabila nilai $\mathrm{Nij}$ negatif mengindikasikan bahwa pertumbuhan sektor i di wilayah acuan lebih cepat jika dibandingkan dengan pertumbuhan sektor i di wilayah analisis.

2) Jika nilai Mij positif mengindikasikan bahwa pertumbuhan sektor i bertumbuh cepat pada wilayah analisis. Sedangkan apabila nilai Mij negatif mengindikasikan bahwa pertumbuhan sektor i bertumbuh lambat di wilayah analisis.

3) Jika nilai Cij positif mengindikasikan bahwa sektor i pada wilayah analisis memiliki daya saing yang lebih baik dibandingkan dengan sektor i pada wilayah lainnya. Sedangkan apabila nilai Cij negatif mengindikasikan bahwa sektor i di wilayah analisis tidak memiliki daya saing yang baik jika dibandingkan dengan sektor i di wilayah lainnya.

\section{Hasil dan Pembahasan}

3.1. Perkembangan Perekonomian Provinsi Nusa Tenggara Timur

Perekonomian Provinsi Nusa Tenggara Timur (NTT) sejak tahun 2015 hingga tahun 2019 selalu mengalami peningkatan. Hal tersebut tercermin dari nilai PDRB atas dasar harga konstan Provinsi NTT yang selalu meningkat setiap tahunnya yaitu dengan peningkatan rata-rata sebesar 5.14 persen. Pada tahun 2019, PDRB Provinsi NTT mencapai 69.3 triliun rupiah rupiah di mana sektor pertanian memberikan kontribusi sebesar 18.5 triliun atau 26.7 persen dan disusul oleh sektor administrasi pemerintahan, pertahanan dan jaminan sosial wajib serta sektor perdagangan besar dan eceran dengan masing-masing kontribusi sebesar 14 persen dan 12.07 persen. Selanjutnya, kontribusi sektoral terbesar terhadap PDRB Provinsi NTT disajikan pada Gambar 1.

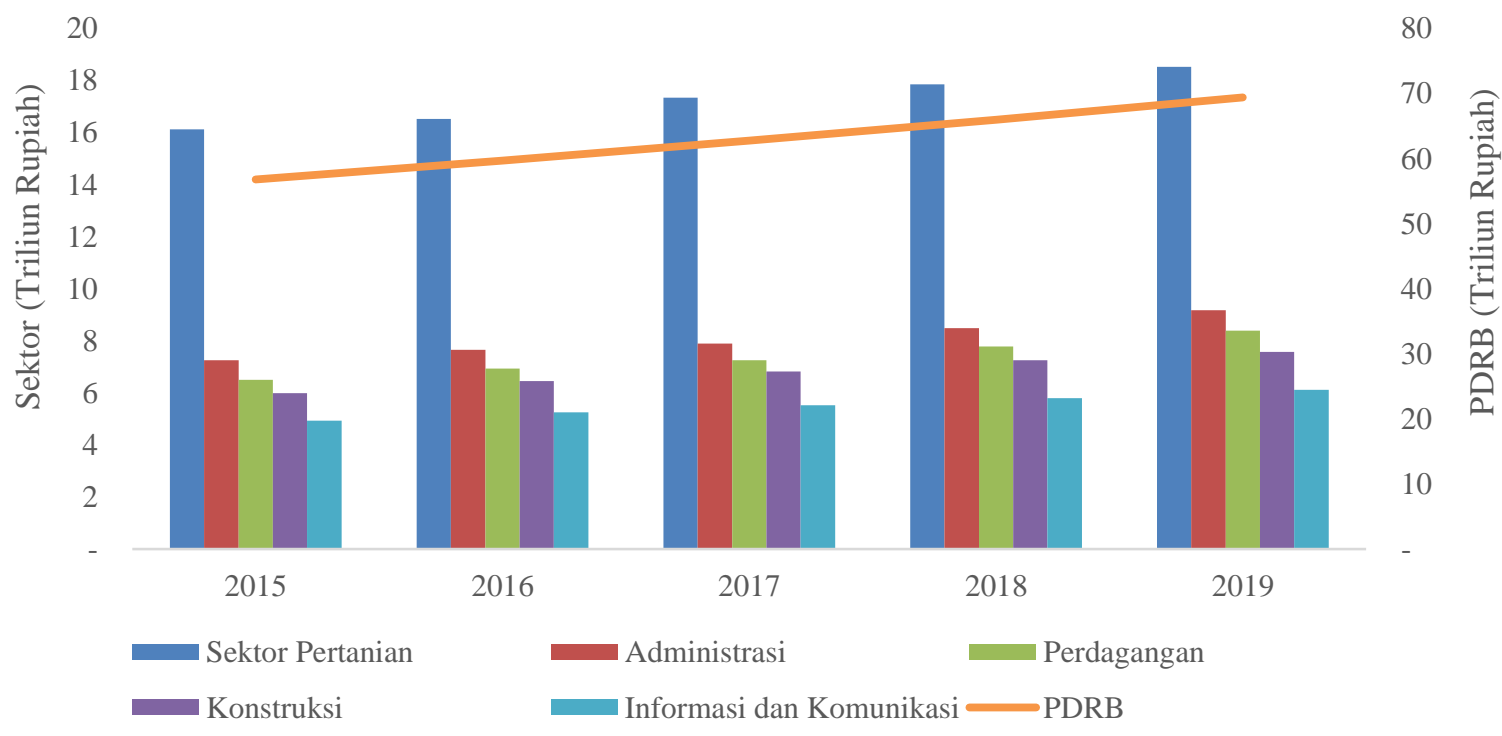

Gambar 1. Kontribusi sektoral terbesar dan PDRB Provinsi NTT 
Berdasarkan Gambar 1, terlihat bahwa terdapat lima sektor yang menopang perekonomian Provinsi NTT dengan kontribusi rata-rata pada setiap sektor 27.49 persen untuk sektor pertanian, 12.85 persen untuk sektor administrasi, 11.70 persen untuk sektor perdagangan, 10.82 persen untuk sektor konstruksi dan 8.77 persen untuk sektor informasi dan komunikasi. Sejak lima tahun terakhir (2015-2019) terdapat kenaikan kontribusi PDRB yang relatif stabil sehingga menyebabkan kenaikan PDRB Provinsi NTT sebesar 5.14 persen. Sektor pertanian menjadi sektor yang memiliki kontribusi terbesar dengan selisih yang cukup jauh dengan sektor administrasi sebagai sektor yang memiliki kontribusi terbesar kedua diikuti oleh sektor perdagangan, konstruksi serta informasi dan komunikasi. Hal tersebut mencerminkan bahwa sektor pertanian menjadi sektor yang sangat dominan bagi perekonomian Provinsi NTT. Namun berdasarkan perhitungan, sejak tahun 2015-2019 tercatat bahwa pertumbuhan sektor pertanian hanya sebesar 3.53 persen atau menjadi sektor ke-14 dengan pertumbuhan tercepat di Provinsi NTT, sedangkan sektor yang memiliki pertumbuhan tercepat adalah sektor penyediaan akomodasi dan makan minum, industri pengolahan dan perdagangan dengan masing-masing memiliki pertumbuhan sebesar 11.5 persen, 6.66 persen dan 6.59 persen (Badan Pusat Statistik, 2020a). Hal tersebut mencerminkan bahwa sektor pertanian meskipun memiliki kontribusi terbesar bagi perekonomian Provinsi NTT namun memiliki pertumbuhan yang cenderung lebih lambat jika dibandingkan dengan sektor lainnya. Beberapa faktor menjadi alasan terkait rendahnya laju pertumbuhan sektor pertanian seperti yang terjadi di Kota Kupang di mana salah satu faktor penyebab adalah adanya konversi lahan pertanian menjadi pemukiman warga (Jahang, 2018). Hal tersebut selaras dengan penelitian Yuendini et al., (2019) yang menyatakan bahwa salah satu faktor penyebab rendahnya laju pertumbuhan sektor pertanian di Provinsi Bali adalah karena adanya konversi lahan menjadi lahan industri lainnya dan menyebabkan lahan pertanian semakin menyempit. Berikut adalah laju pertumbuhan sektor yang memiliki kontribusi terbesar bagi PDRB Provinsi NTT yang disajikan pada Gambar 2.

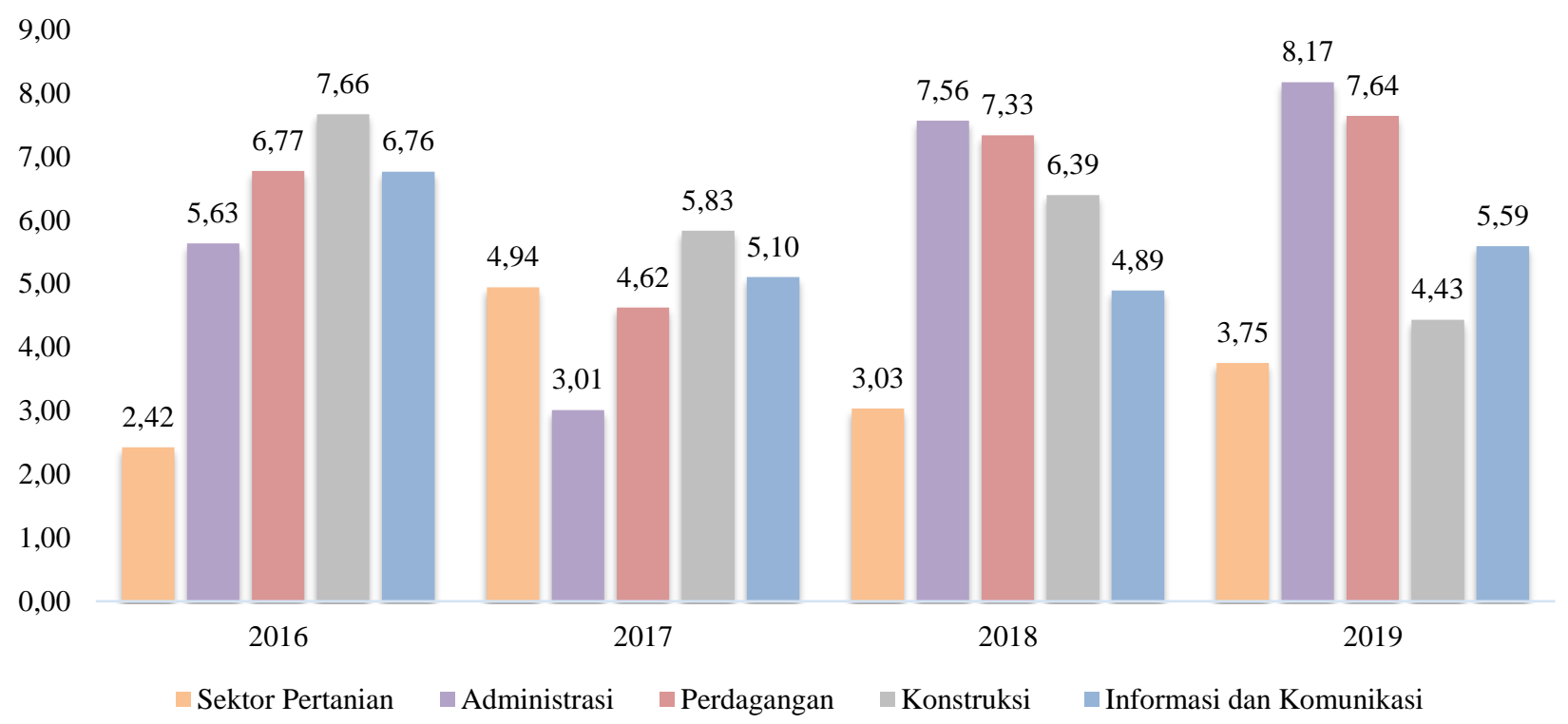

Gambar 2. Laju pertumbuhan sektoral terhadap PDRB Provinsi NTT tahun 2015-2019 (\%)

\subsection{Klassen Typology Method}

Klassen Typology Method digunakan untuk melihat pola dan struktur pertumbuhan ekonomi di Provinsi NTT dalam kurun waktu analisis. Hal tersebut selaras dengan penelitian Putra et al., (2017) yang menggunakan Klassen Typology Method untuk menganalisis pola dan struktur pertumbuhan di Provinsi Riau. Berdasarkan hasil analisis, sektor pertanian berada pada kuadran II yang mencerminkan bahwa sektor pertanian merupakan sektor yang maju namun tertekan. Hal ini mengindikasikan bahwa kegiatan utama yang berada di Provinsi NTT telah tertekan dengan kegiatan lainnya sehingga menyebabkan kegiatan utama di Provinsi NTT menjadi terancam. Penelitian Novitasari et al., (2019) tentang potensi pengembangan sektor ekonomi di Provinis Jawa Barat juga menunjukkan hal yang sama bahwa sektor utama (pertanian) telah berada pada kuadran II di beberapa Kabupaten dan Kota di Provinsi Jawa Barat karena mulai tertekan oleh sektor lain. 
Data terkait laju pertumbuhan sektor pertanian di Provinsi NTT menunjukkan fluktuasi dengan kecenderungan menurun dan berada di bawah sektor lainnya yang memiliki laju pertumbuhan lebih cepat. Oleh sebab itu, perlu dilakukan upaya lebih dari pemerintah Provinsi NTT untuk dapat menstabilkan laju pertumbuhan sektor pertanian. Hal ini mengingat bahwa sangat dominannya sektor pertanian berkontribusi bagi perekonomian Provinsi NTT dan nasional sehingga apabila terjadi gejolak di sektor pertanian, akan berdampak bagi perekonomian Provinsi NTT dan nasional.

Sektor konstruksi dan administrasi merupakan sektor yang berada pada kuadran I yang mencerminkan bahwa sektor tersebut merupakan sektor yang maju dan tumbuh dengan pesat, hal ini dapat terlihat dari laju pertumbuhan kedua sektor tersebut yang memiliki nilai cukup tinggi dibanding sektor lainnya. Secara dominan, sektor-sektor lain di Provinsi NTT berada pada kuadran III dan IV di mana hal ini menunjukkan bahwa di Provinsi NTT masih banyak sektor yang harus dikembangkan lebih jauh mengingat potensialnya Provinsi NTT untuk dijadikan salah satu kontributor perekonomian Indonesia dan sesuai dengan salah satu Nawa Cita Presiden Republik Indonesia untuk membangun Indonesia dari pinggiran dengan memperkuat daerahdaerah dan desa dalam kerangka negara kesatuan. Berikut adalah hasil analisis menggunakan Klassen Typology Method yang disajikan pada Tabel 2.

\section{Tabel 2. Klassen Typology Method sektoral Provinsi Nusa Tenggara Timur (2015-2019)}

\begin{tabular}{|c|c|c|c|}
\hline No & Sektor & Kuadran & Kriteria \\
\hline 1 & Pertanian, kehutanan dan perikanan & 2 & Maju tapi tertekan \\
\hline 2 & Pertambangan dan penggalian & 3 & Potensial dan dapat berkembang \\
\hline 3 & Industri pengolahan & 3 & Potensial dan dapat berkembang \\
\hline 4 & Pengadaan listrik dan gas & 3 & Potensial dan dapat berkembang \\
\hline 5 & $\begin{array}{l}\text { Pengadaan air, pengolahan sampah, } \\
\text { limbah dan daur ulang }\end{array}$ & 4 & Relatif tertinggal \\
\hline 6 & Konstruksi & 1 & Maju dan tumbuh pesat \\
\hline 7 & $\begin{array}{l}\text { Perdagangan besar dan eceran; reparasi } \\
\text { mobil dan sepeda motor }\end{array}$ & 3 & Potensial dan dapat berkembang \\
\hline 8 & Transportasi dan pergudangan & 2 & Maju tapi tertekan \\
\hline 9 & $\begin{array}{l}\text { Penyediaan akomodasi dan makan } \\
\text { minum }\end{array}$ & 3 & Potensial dan dapat berkembang \\
\hline 10 & Informasi dan komunikasi & 2 & Maju tapi tertekan \\
\hline 11 & Jasa keuangan dan asuransi & 4 & Relatif tertinggal \\
\hline 12 & Real estat & 4 & Relatif tertinggal \\
\hline 13 & Jasa perusahaan & 4 & Relatif tertinggal \\
\hline 14 & $\begin{array}{l}\text { Administrasi pemerintahan, pertahanan } \\
\text { dan jaminan sosial wajib }\end{array}$ & 1 & Maju dan tumbuh pesat \\
\hline 15 & Jasa pendidikan & 2 & Maju tapi tertekan \\
\hline 16 & Jasa kesehatan dan kegiatan sosial & 2 & Maju tapi tertekan \\
\hline 17 & Lain-lain & 2 & Maju tapi tertekan \\
\hline
\end{tabular}

Sumber: Data Sekunder (Diolah 2020)

\subsection{Location Quotient (LQ)}

Location Quotient (LQ) pada penelitian ini digunakan untuk mengetahui sektor unggulan yang berada di Provinsi NTT pada tahun analisis Berdasarkan hasil penelitian, diketahui bahwa sektor pertanian bersama dengan sektor transportasi dan pergudangan, informasi dan komunikasi, administrasi pemerintahan, jasa pendidikan, jasa kesehatan dan kegiatan sosial serta sektor lainnya berada pada kriteria basis yang mencerminkan bahwa sektor tersebut merupakan sektor unggulan yang ada di Provinsi NTT. Hal ini mengindikasikan bahwa sektor tersebut telah mampu memenuhi kebutuhan di dalam provinsi dan sebagian dari surplusnya dapat dimanfaatkan oleh wilayah lain. Tingginya produksi pertanian di Provinsi NTT tidak terlepas dari banyaknya masyarakat yang telah melakukan diversifikasi usahatani sehingga dapat meingkatkan aspek pendapatan petani juga menjadikan produksi pertanian meningkat (Leki, 2010). Beberapa penelitian juga memiliki hasil yang cenderung sama di mana sektor pertanian telah menjadi sektor basis di beberapa wilayah di Indonesia seperti penelitian (Diartho et al., 2020) terkait penelitiannya tentang perencanaan pengembangan kawasan perdesaan berbasis potensi di bagian selatan Provinsi Jawa Timur yang menyatakan bahwa sebagian besar kecamatan di Kabupaten Banyuwangi memiliki basis pada sektor pertanian baik komoditas padi atataupun jagung.

Sektor pertanian yang memiliki kriteria basis dapat diartikan memiliki kontribusi yang besar terhadap perkonomian Provinsi NTT. Selain itu, serapan tenaga kerja di Provinsi NTT juga 
didominasi oleh sektor pertanian dengan nilai kontribusi sebesar 48.7 persen dari total penduduk yang berada pada usia angkatan kerja (Badan Pusat Statistik, 2020b). Oleh sebab itu, dikarenakan peranannya yang sangat penting maka sektor pertanian perlu untuk dikembangkan lebih lanjut oleh pemerintah karena hampir sebagian dari jumlah penduduk pada usia angkatan kerja bekerja pada sektor pertanian. Namun, pembangunan sektor lain yang berada pada kriteria basis juga harus ditingkatkan karena sektor-sektor yang berada pada kriteria basis akan mampu mengembangkan sektor non basis lainnya (Sari, 2018). Selanjutnya, hasil analisis Location Quotient disajikan pada Tabel 3.

Tabel 3. Hasil perhitungan Location Quotient di Provinsi Nusa Tenggara Timur (2015-2019)

\begin{tabular}{|c|c|c|c|c|c|c|c|c|}
\hline \multirow[b]{2}{*}{ No } & \multirow{2}{*}{ Sektor } & \multicolumn{5}{|c|}{ Tahun } & \multirow{2}{*}{$\begin{array}{l}\text { Rata- } \\
\text { rata }\end{array}$} & \multirow{2}{*}{ Kriteria } \\
\hline & & 2015 & 2016 & 2017 & 2018 & 2019 & & \\
\hline & Pertanian, kehutanan dan perikanan & 0,73 & 2,07 & 2,09 & 2,08 & 2,11 & 1,82 & Basis \\
\hline & Pertambangan dan penggalian & 0,06 & 0,17 & 0,17 & 0,17 & 0,17 & 0,15 & Non basis \\
\hline & Industri pengolahan & 0,02 & 0,06 & 0,06 & 0,06 & 0,06 & 0,05 & Non basis \\
\hline & Pengadaan listrik dan gas & 0,02 & 0,07 & 0,07 & 0,07 & 0,07 & 0,06 & Non basis \\
\hline & $\begin{array}{l}\text { Pengadaan air, pengolahan sampah, limbah } \\
\text { dan daur ulang }\end{array}$ & 0,27 & 0,77 & 0,77 & 0,80 & 0,83 & 0,69 & Non basis \\
\hline 6 & Konstruksi & 0,36 & 1,05 & 1,05 & 1,06 & 1,04 & 0,91 & Non basis \\
\hline & $\begin{array}{l}\text { Perdagangan besar dan eceran; reparasi mobil } \\
\text { dan sepeda motor }\end{array}$ & 0,31 & 0,86 & 0,84 & 0,84 & 0,82 & 0,73 & Non basis \\
\hline & Transportasi dan pergudangan & 0,42 & 1,23 & 1,22 & 1,23 & 1,25 & 1,07 & Basis \\
\hline & Penyediaan akomodasi dan makan minum & 0,08 & 0,24 & 0,22 & 0,21 & 0,19 & 0,19 & Non basis \\
\hline & Informasi dan komunikasi & 0,55 & 1,63 & 1,67 & 1,74 & 1,79 & 1,48 & Basis \\
\hline & Jasa keuangan dan asuransi & 0,32 & 0,94 & 0,95 & 0,95 & 0,96 & 0,83 & Non basis \\
\hline & Real estat & 0,28 & 0,84 & 0,83 & 0,82 & 0,84 & 0,72 & Non basis \\
\hline & Jasa perusahaan & 0,05 & 0,14 & 0,15 & 0,16 & 0,17 & 0,13 & Non basis \\
\hline & $\begin{array}{l}\text { Administrasi pemerintahan, pertahanan dan } \\
\text { jaminan sosial wajib }\end{array}$ & 1,34 & 3,68 & 3,67 & 3,65 & 3,58 & 3,18 & Basis \\
\hline & Jasa pendidikan & 0,92 & 2,63 & 2,71 & 2,68 & 2,68 & 2,32 & Basis \\
\hline & Jasa kesehatan dan kegiatan sosial & 0,65 & 1,91 & 1,92 & 1,91 & 1,91 & 1,66 & Basis \\
\hline & Lain-lain & 0,40 & 1,17 & 1,20 & 1,23 & 1,29 & 1,06 & Basis \\
\hline
\end{tabular}

Sumber: Data sekunder diolah (2020)

\subsection{Analisis Shift Share}

Analisis Shift Share digunakan untuk mengetahui hubungan sektor pertanian dan sektor lainnya secara nasional terhadap sektor yang sama di Provinsi NTT. Analisis Shift Share dikelompokkan menjadi tiga komponen yaitu komponen Pertumbuhan Nasional (N), Pertumbuhan Proporsional (M) dan Pertumbuhan Daya Saing (C). Hasil analisis Shift Share selanjutnya disajikan pada Tabel 4.

Berdasarkan hasil analisis, terlihat bahwa Pertumbuhan Nasional $(\mathrm{N})$ pada sektor pertanian memiliki nilai yang positif dengan nilai sebesar 3.336.153,44. Hal ini mengindikasikan bahwa pertumbuhan sektor pertanian di Provinsi NTT memiliki pertumbuhan yang lebih cepat dibandingkan dengan pertumbuhan sektor pertanian secara nasional. Pertumbuhan Proporsional (M) pada hasil analisis juga menunjukkan nilai yang positif untuk sektor pertanian dengan nilai sebesar 522.623,08. Hal tersebut mengindikasikan bahwa sektor pertanian merupakan sektor yang secara dominan menggerakan perekonomian Provinsi NTT dan diikuti oleh sektor lainnya seperti sektor informasi dan komunikasi, konstruksi, administrasi pemerintahan dan perdagangan.

Pertumbuhan lain yang diukur adalah Pertumbuhan Daya Saing (C) di mana pada hasil analisis Shift Share, sektor pertanian menunjukkan nilai yang negatif yaitu $-125.977,34$. Hal tersebut mencerminkan bahwa sektor pertanian memiliki daya saing yang kurang jika dibandingkan dengan sektor pertanian provinsi lain. Hal tersebut selaras dengan penelitian yang dilakukan oleh Masfufah et al., (2018) tentang peranan sektor pertanian terhadap perekonomian Provinsi Jawa Timur Tahun 2004-2013 yang menyatakan bahwa sektor pertanian belum memiliki keunggulan kompetitif. Oleh sebab itu, pemerintah perlu melakukan upaya peningkatan daya saing secara menyeluruh di berbagai sektor di Provinsi NTT mengingat sebagian besar sektor di Provinsi NTT memiliki nilai yang negatif. Beberapa hal yang perlu dilakukan oleh pemerintah agar dapat meningkatkan daya saing sektor pertanian adalah dengan melakukan pembangunan pertanian dari hulu hingga hilir seperti pengaplikasian alat mesin pertanian hingga pembangunan infrastruktur guna mendukung berjalannya proses distribusi komoditas pertanian hingga ke pihak konsumen. Selain itu, untuk meningkatkan kapasitas sumberdaya manusia, perlu diadakan pelatihan dan pembinaan kepada para pelaku industri untuk melakukan 
penerapan sistem Good Agriculture Practice (GAP) agar terciptanya inovasi yang menyebabkan peningkatan nilai tambah produk pertanian (Baso \& Anindita, 2018).

Tabel 4. Hasil analisis Shift Share Provinsi Nusa Tenggara Timur tahun 2015-2019

\begin{tabular}{|c|c|c|c|c|c|}
\hline \multirow[b]{2}{*}{ No } & \multirow[b]{2}{*}{ Sektor } & \multicolumn{3}{|c|}{ Komponen } & \multirow{2}{*}{$\begin{array}{l}\text { Pergeseran } \\
\text { Struktur } \\
\text { Ekonomi }\end{array}$} \\
\hline & & $\mathrm{N}$ & M & $\mathrm{C}$ & \\
\hline 1 & Pertanian, kehutanan dan perikanan & $3.336 .153,44$ & $522.623,08$ & $-125.977,34$ & $3.732 .799,18$ \\
\hline & Pertambangan dan penggalian & $172.352,11$ & $8.732,75$ & $63.548,80$ & $244.633,67$ \\
\hline & Industri pengolahan & $146.887,90$ & $25.979,16$ & $82.682,28$ & $255.549,35$ \\
\hline & Pengadaan listrik dan gas & $8.466,83$ & $1.475,94$ & $4.110,97$ & $14.053,74$ \\
\hline 5 & $\begin{array}{l}\text { Pengadaan air, pengolahan sampah, } \\
\text { limbah dan daur ulang }\end{array}$ & $8.269,43$ & $1.835,90$ & $-3.585,67$ & $6.519,66$ \\
\hline 6 & Konstruksi & $1.238 .422,64$ & $322.947,22$ & $30.339,55$ & $1.591 .709,42$ \\
\hline 7 & $\begin{array}{l}\text { Perdagangan besar dan eceran; reparasi } \\
\text { mobil dan sepeda motor }\end{array}$ & $1.343 .580,40$ & $259.729,90$ & $631.461,20$ & $2.234 .771,50$ \\
\hline 8 & Transportasi dan pergudangan & $590.304,43$ & $193.576,81$ & $-139.725,04$ & $644.156,20$ \\
\hline & Penyediaan akomodasi dan makan minum & $69.922,75$ & $16.754,09$ & $103.393,81$ & $190.070,65$ \\
\hline & Informasi dan komunikasi & $1.018 .767,30$ & $404.990,97$ & $-762.679,58$ & $661.078,69$ \\
\hline & Jasa keuangan dan asuransi & $450.422,11$ & $124.220,20$ & $-104.644,14$ & $469.998,18$ \\
\hline & Real estat & $301.438,35$ & $56.293,24$ & $-71.038,48$ & $286.693,11$ \\
\hline & Jasa perusahaan & $34.137,74$ & $13.467,15$ & $-48.346,87$ & $-741,98$ \\
\hline & $\begin{array}{l}\text { Administrasi pemerintahan, pertahanan } \\
\text { dan jaminan sosial wajib }\end{array}$ & $1.499 .753,49$ & $269.057,29$ & $627.218,20$ & $2.396 .028,97$ \\
\hline & Jasa pendidikan & $1.025 .528,51$ & $211.280,18$ & $-107.339,00$ & $1.129 .469,69$ \\
\hline & Jasa kesehatan dan kegiatan sosial & $250.841,21$ & $77.315,15$ & $-21.761,45$ & $306.394,90$ \\
\hline & Lain-lain & $251.576,18$ & $104.332,65$ & $-192.039,34$ & $163.869,49$ \\
\hline & TOTAL & $11.746 .824,80$ & $2.614 .611,68$ & $-34.382,08$ & $14.327 .054,40$ \\
\hline
\end{tabular}

\section{Simpulan}

Provinsi Nusa Tenggara Timur merupakan provinsi yang perlu diberikan perhatian lebih oleh pemerintah untuk dapat mengembangkan potensinya khususnya potensi di sektor pertanian. Hasil penelitian menunjukkan bahwa perekonomian Provinsi NTT secara dominan ditopang oleh sektor pertanian, namun sektor ini secara perlahan mengalami kesulitan untuk tumbuh. Hal tersebut tercermin dari hasil perhitungan laju pertumbuhan sektoral yang menyatakan bahwa sektor pertanian menempati peringkat ke-14 dari 17 sektor yang memiliki laju pertumbuhan tercepat di Provinsi NTT. Beberapa sektor lain seperti sektor administrasi dan perdagangan bahkan cenderung memiliki laju pertumbuhan yang lebih cepat sehingga perlu adanya upaya khusus dari pemerintah untuk dapat meningkatkan kembali laju pertumbuhan sektor pertanian seperti pengembangan infrastruktur pertanian, penerapan teknologi budidaya pertanian hingga pendistribusian hasil pertanian.

\section{Pustaka}

Abidin, Z. (2015). Aplikasi Analisis Shift Share pada Transformasi Sektor Pertanian dalam Perekonomian Wilayah di Sulawesi Tenggara. Jurnal Informatika Pertanian, 24(2), 165-178.

Ai, T., \& Wardoyo, R. (2015). Fuzzy-Klassen Model for Development Disparities Analysis based on Gross Regional Domestic Product Sector of a Region. International Journal of Computer Applications, 123(7), 17-22. https://doi.org/10.5120/ijca2015905389

Badan Pusat Statistik. (2020a). PDRB ADH Konstan 2010 Menurut Lapangan Usaha (Juta Rupiah). Badan Pusat Statistik Provinsi Nusa Tenggara Timur. https://ntt.bps.go.id/indicator/52/436/2/-seri-2010-pdrb-adh-konstan-2010-menurutlapangan-usaha.html

Badan Pusat Statistik. (2020b). Penduduk Berumur 15 Tahun Ke Atas yang Bekerja Menurut Lapangan Pekerjaan Utama. Badan Pusat Statistik Provinsi Nusa Tenggara Timur. https://ntt.bps.go.id/indicator/6/52/1/penduduk-berumur-15-tahun-ke-atas-yangbekerja-menurut-lapangan-pekerjaan-utama.html

Bank Indonesia. (2020). Profil Provinsi Nusa Tenggara Timur. Bank Indonesia. https://www.bi.go.id/id/publikasi/kajian-ekonomiregional/ntt/profil/Contents/Demografi.aspx

Baso, R. L., \& Anindita, R. (2018). Analisis Daya Saing Kopi Indonesia. Jurnal Ekonomi Pertanian Dan Agribisnis, 2(1), 1-9. https://doi.org/10.21776/ub.jepa.2018.002.01.1

Cieślak, I., Pawlewicz, K., \& Pawlewicz, A. (2019). Sustainable development in Polish regions: A shift-share analysis. Polish Journal of Environmental Studies, 28(2), 565-575. 
https: / / doi.org/10.15244/pjoes / 85206

Crawley, A., Beynon, M., \& Munday, M. (2013). Making Location Quotients More Relevant as a Policy Aid in Regional Spatial Analysis. Urban Studies, 50(9), $1854-1869$. https: / / doi.org/10.1177/0042098012466601

Diartho, H. C., Lestari, E. K., Yunitasari, D., Lutfi, A., \& Muslihatiningsih, F. (2020). Perencanaan Pengembangan Kawasan Perdesaan Berbasis Potensi di Bagian Selatan Provinsi Jawa Timur (Studi: Kabupaten Banyuwangi). Media Trend, 15(1), 62-73.

Fracasso, A., \& Marzetti, V. G. (2018). Estimating dynamic localization economies: the inadvertent success of the specialization index and the location quotient. Regional Studies, 52(1), 119-132. https:/ / doi.org/ 10.1080/00343404.2017.1281388

Hidayat, E., \& Supriharjo, R. (2014). Identifikasi Sub Sektor Unggulan Kecamatan di Kabupaten Lombok Tengah. Jurnal Teknik Pomits, https: / /doi.org/http:/ /dx.doi.org/10.12962/j23373539.v3i1.5746

Jahang, B. (2018). Alih Fungsi Lahan Pertanian Terus Meningkat. Antara News. https:/ / kupang.antaranews.com/berita/6335/alih-fungsi-lahan-pertanian-terus-meningkat

Jumiyanti, K. R. (2018). Analisis Location Quotient dalam Penentuan Sektor Basis dan Non Basis di Kabupaten Gorontalo. Gorontalo Development Review, 1(1), 29. https://doi.org/10.32662/golder.v1i1.112

Kementerian Pertanian. (2020). Produksi Tanaman Pangan Provinsi Nusa Tenggara Timur. Pusat Data Dan Informasi Pertanian. https://aplikasi2.pertanian.go.id/bdsp/id/komoditas

Leki, S. (2010). Kajian Kebijakan Pertanian dalam Memenuhi Kebutuhan Dasar Penduduk di NTT. In Perkumpulan Pikul.

Liu, H., Jia, Y., Niu, C., \& Gan, Y. (2019). Spatial Pattern Analysis of Regional Water Use Profile Based on the Gini Coefficient and Location Quotient. Journal of the American Water Resources Association, 55(5), 1349-1366. https://doi.org/10.1111/1752-1688.12790

Masfufah, S., Priyono, T. H., \& Hanim, A. (2018). Analisis Struktur Perekonomian Dan FaktorFaktor Yang Memengaruhi Pertumbuhan Ekonomi Sumatera Selatan. Jurnal Ekonomi Dan Kebijakan Pembangunan, 2(1), 47-59. https://doi.org/10.29244/jekp.2.1.47-59

Morrissey, K. (2016). A location quotient approach to producing regional production multipliers for the Irish economy. Papers in Regional Science, 95(3), 491-506. https://doi.org/10.1111/pirs. 12143

Novitasari, R., Sulistyowati, L., \& Karmana, M. H. (2019). Analisis Potensi Ekonomi Dalam Pembangunan Pertanian Kabupaten/Kota Di Provinsi Jawa Barat. Mimbar Agribisnis: Jurnal Pemikiran Masyarakat Mmiah Berwawasan Agribisnis, 5(2), 316. https: / /doi.org/ 10.25157/ma.v5i2.2286

Putra, F. D., Kifli, F. W., \& Ambarsari, A. (2017). Analisis Klassen Typology Sektor Ekonomi Provinsi Riau. Jurnal Masepi, 6(April), 487-492.

Sari, F. W. A. W., \& Bangun, R. H. B. (2019). Analisis Peranan Sektor Pertanian, Kehutanan dan Perikanan pada Perekonomian Kabupaten Deli Serdang. Journal Agroland, 26(3), $198-211$.

Sari, S. R. (2018). Kontribusi Sektor Pertanian Dalam Struktur Ekonomi Di Kabupaten Kaur Provinsi Bengkulu. Jurnal AGRISEP: Kajian Masalah Sosial Ekonomi Pertanian Dan Agribisnis, 17(2), 175-186. https://doi.org/10.31186/jagrisep.17.2.175-186

Supriyadi, B., Bahrullah, A., \& Djazuli, A. (2016). Analysis of Social Economics District Proliferation in Indonesia. The IAFOR International Conference on the Social Science-Dubai 2016, 1-9.

Yuendini, E. P., Rachmi, I. N., Nurul, N., Puspitasari, A., \& Harini, R. (2019). Analisis Potensi Ekonomi Sektor Pertanian dan Sektor Pariwisata di Provinsi Bali Menggunakan Teknik Analisis Regional. Jurnal Geografi: Media Informasi Pengembangan Dan Profesi Kegeografian, 16(2), 128-136. https://doi.org/10.15294/jg.v16i2.20831 